\title{
Shore fishes and biogeographic subdivisions of the Tropical Eastern Pacific
}

\author{
D. Ross Robertson ${ }^{1, *, * *}$, Katie L. Cramer ${ }^{2, * *}$ \\ ${ }^{1}$ Smithsonian Tropical Research Institute, Balboa, Panamá \\ ${ }^{2}$ Center for Marine Biodiversity and Conservation, Scripps Institution of Oceanography, University of California, San Diego, \\ California, USA \\ Address for correspondence: DRR, STRI, Unit 9100, Box 0948, DPO, AA 34002, USA
}

ABSTRACT: We examined the geographic distributions of 1135 species of resident shore fishes to assess biogeographic subdivision of the Tropical Eastern Pacific (TEP), which stretches from the Gulf of California to northern Peru. Using hierarchical clustering refined by Analysis of Similarity (ANOSIM), we determined geographic groupings in the distributions of the entire fauna, of regional endemics and of 3 functional (habitat) groups of species. We also examined the distributions of local endemics throughout the TEP and how differences in faunal size versus faunal composition among sites contribute to the subdivision pattern. Our results indicate that: (1) the continental coast contains 2 provinces, the Cortez (Gulf of California and lower Pacific Baja) and the Panamic (southward), each of which has a peak in abundance of local endemics and of overall species richness; (2) the northern and southern boundaries of the TEP are located near Magdalena Bay on Baja California $\left(\sim 25^{\circ} \mathrm{N}\right)$ and the southern shore of the Gulf of Guayaquil $\left(\sim 4^{\circ} \mathrm{S}\right)$, respectively; and (3) the 5 oceanic islands/archipelagos collectively represent a third, Ocean Island Province. Relative to mainland areas, the fauna of the ocean islands is smaller, has a different functional-group composition, and includes more transpacific species and more highly localized endemics. The 3-province pattern probably developed in response to the formation of the Gulf of California, the rise of the Isthmus of Panama, immigration from the north, south and west to the TEP, and differing environmental conditions between and within provinces. In contrast, barriers to dispersal within this geographically simple region are weak and likely had much less influence.

KEY WORDS: Tropical eastern Pacific · Zoogeography • Dispersal barrier · Gulf of California - Isthmus of Panama · Shore fishes $\cdot$ Speciation

Resale or republication not permitted without written consent of the publisher

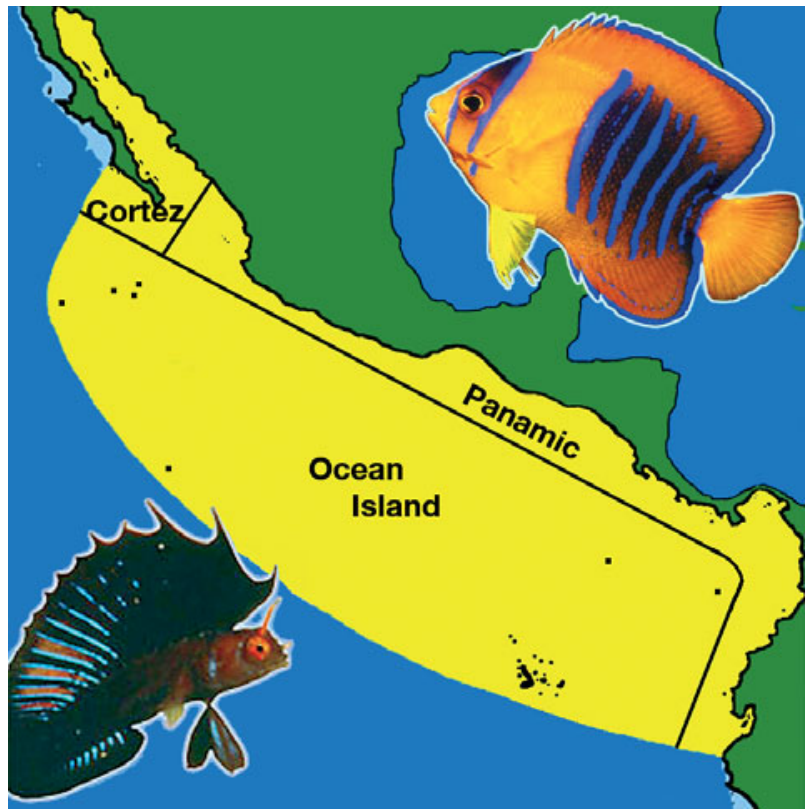

Regional distributions of 1135 near-shore fish species (see www.stri.org/sftep) indicate that the Tropical Eastern Pacific is divided into 3 biogeographic provinces.

Illustration: Ernesto Peña

\section{INTRODUCTION}

In his pioneering analysis of global marine biogeography Briggs (1974) identified 4 major tropical 'regions', which represent centers of high diversity and endemism for shore-living organisms: the Indo-West Pacific, the East Pacific, the West Atlantic, and the East Atlantic. His and earlier analyses of the distributions of shore fishes (e.g. Walker 1960, Rosenblatt 1967) and other tropical organisms (Ekman 1953) on the Pacific 
coast of the Americas indicated that the Tropical Eastern Pacific (TEP) spans the continental shore between southern Baja California to northern Peru, and includes the Galapagos and the 4 other isolated ocean islands and archipelagos - the Revillagigedo group, Clipperton, Cocos, and Malpelo (Fig. 1A).

Briggs (1974) used information on the regional distribution of local endemic reef fishes and arbitrarily set a minimum endemism rate of $10 \%$ to distinguish 2 mainland provinces within the TEP: the Mexican and the Panamic. He placed the northern limit of the TEP and of his Mexican Province at $\sim 25^{\circ} \mathrm{N}$, not only on the Pacific coast of Baja but also inside the Gulf of California, and the lower limit of the latter at $\sim 16^{\circ} \mathrm{N}$, on the northern edge of the Gulf of Tehuantepec, Mexico. He excluded the northern and central Gulf of California (above $25^{\circ} \mathrm{N}$ ) from the TEP, asserting that it has a largely temperate fauna that is allied most strongly to the fauna of the Californian Province, which extends north from $25^{\circ} \mathrm{N}$ along the Pacific coast of the Baja Peninsula. His Panamic Province stretched from $\sim 16^{\circ} \mathrm{N}$ to $\sim 3^{\circ} \mathrm{S}$ at the border between Ecuador and Peru (see Fig. 1B). Based on literature indicating high levels of local endemism among algae, corals, mollusks, and crabs as well as shore fishes (Walker 1966), Briggs (1974) recognized the Galapagos Archipelago as a third province of the TEP.

Earlier, Walker (1960) defined 2 provinces in Mexico based on the distributions of locally endemic reef fishes: a Cortez Province, consisting of Pacific coast of Baja below $25^{\circ} \mathrm{N}$, plus all of the Gulf of California, and a Mexican Province for the remainder. Later information (Rosenblatt 1974, Thomson et al. 1979) showed that tropical reef fishes are more widely distributed in the Gulf of California than Briggs (1974) realized, supporting Walker's view that most or all of that Gulf is part of the TEP.

Within the TEP there are 2 major breaks in the distribution of shoreline reef habitats. These stretches of sand and mud shorelines are known as the Sinaloan Gap (370 $\mathrm{km}$ of shoreline in the SE Gulf of California) and the Central American Gap ( 1000 km of shoreline from the Gulf of Tehuantepec, southern Mexico, to El Salvador). These 2 gaps define the breakpoints separating the 3 mainland provinces (Cortez, Mexican, and Panamic) as delimited by Hastings (2000) (and see Springer 1959, and Fig. 1A here) based on reef fish faunal affinities.

The most recent formal subdivision of the TEP, as part of a general scheme for all global shorelines, by Spalding et al. (2007), differs significantly in 3 ways from all previous schemes: (1) The northern limit of the TEP was set at $\sim 20^{\circ} \mathrm{N}$ on the mainland, well south of the boundary recognized by Walker (1960), Briggs (1974), and Hastings (2000); all of Baja and the Gulf of California were excluded from the TEP and included as part of a warm temperate 'NE Pacific Biorealm', equivalent to the California Province of Briggs (1974). (2) The southern limit of the TEP followed the limit set by a study of crustacean distributions (Boschi 2000, our Fig. $1 \mathrm{C})$, and was placed further south $\left(7^{\circ} \mathrm{S}\right)$, than the limit set by Briggs (1974) and Hastings (2000) $\left(3^{\circ}\right.$ to $4^{\circ} \mathrm{S}$ ). (3) The TEP was split into 2 provinces, the Galapagos and the remainder of the region (see Fig. 1D).

The northern and southern boundaries of the TEP as defined by all of these studies are not 'hard' barriers that physically prevent dispersal of adult or larval fishes. Rather they relate mainly to relatively sharp temperature gradients between tropical and temperate conditions. As environmental conditions around those boundary areas fluctuate considerably over time and space, so do the range limits of TEP shore fishes and other organisms. During El Niño events waters along the continental shorelines to the north and south of the TEP warm considerably, and the ranges of many TEP endemics expand beyond, sometimes well beyond, their normal regional limits. Chirichigno \& Vélez (1998) and Love et al. (2005) present summaries relating to such temporary southern and northern range extensions by shore fishes.

The only zoogeographic studies to date that have analyzed the faunal relationships between all 5 ocean islands and the mainland of the TEP are Hastings (2000) on chaenopsid blennies and Glynn \& Ault (2000) on stony corals throughout the TEP and in the central Pacific.

Here, we examine biogeographic partitioning of the entire TEP from the perspective of its shore fish fauna, using more comprehensive information on the distributions of those fishes than was available to previous workers. We assess levels of faunal similarity and local endemism among different parts of the TEP to provide answers to 3 questions: (1) Where do the northern and southern boundaries of the TEP lie? (2) How many continental provinces are there in the TEP, and where do boundaries between provinces occur? (3) Should the 5 ocean islands be considered as one or more provinces of the TEP? Finally, we considered the historical origins of the provincial arrangement of the TEP indicated by our analyses.

\section{MATERIALS AND METHODS}

Species database. The zoogeographic database in Robertson \& Allen (2006) that provides data on the distribution of 1261 shore fish species currently known in shallow water (0 to $100 \mathrm{~m}$ depth) in the TEP was used in the present study. That database is a synthesis of information obtained from a bibliography of $>1100$ primary and secondary sources from the scientific literature, as well as surveys by D.R.R. in Mexico, El Salvador, Costa 
Rica, Panama and all 5 oceanic islands. Further, understanding of the limits of distributions of shore fishes throughout the Gulf of California and along the coast of Baja has been greatly enhanced by 2 recent reviews: Findley et al. (2003) and Love et al. (2005).
Our database includes 1135 species of 'TEP residents', species whose abundance and/or distributions indicate they have self-sustaining populations in the region (cf. Robertson et al. 2004). Of those, 897 are 'TEP endemics', species whose ranges are entirely or

\begin{tabular}{|l|l|l|}
\hline $\begin{array}{l}\text { Island A } \\
\text { Island B }\end{array}$ & Cortez & Panamic \\
Mexican & Californian and Peruvian & Sinaloan and Central American Gaps \\
\hline
\end{tabular}
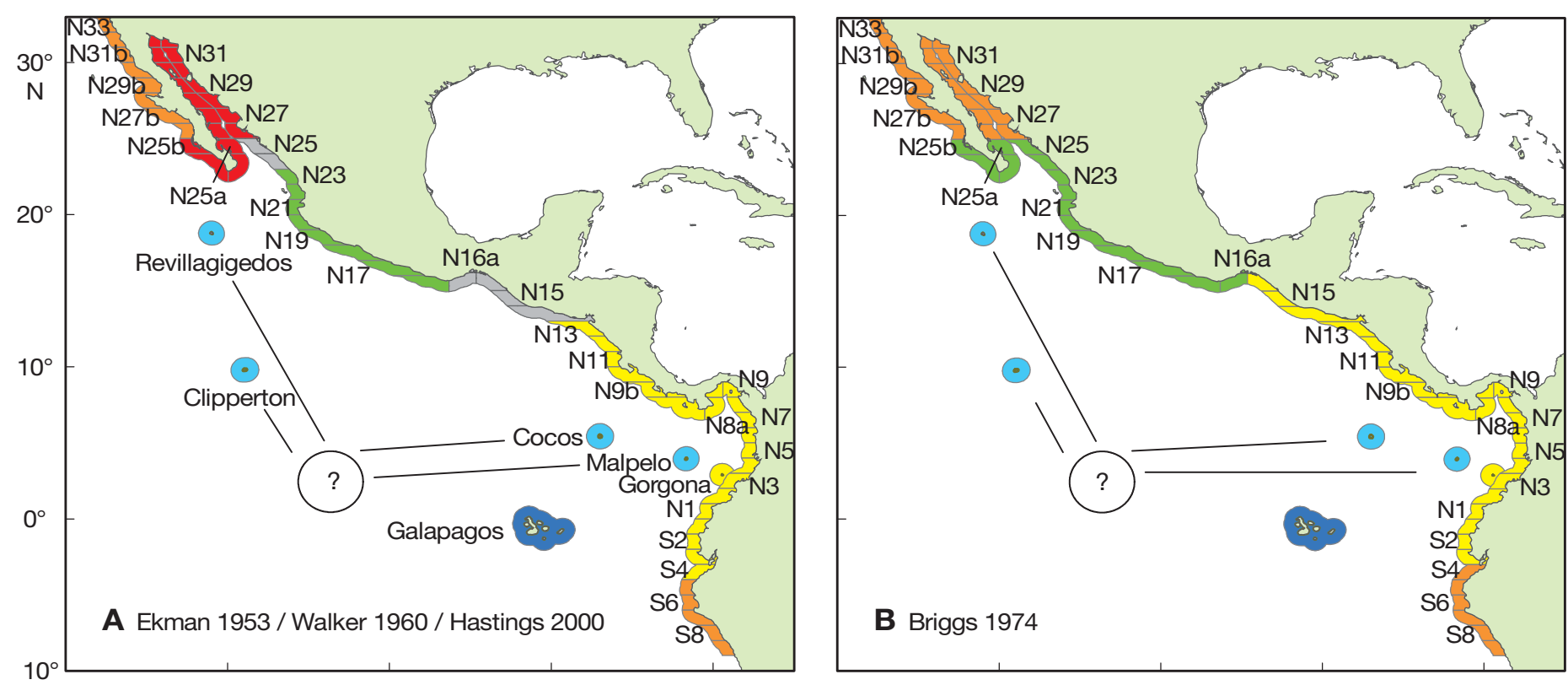

$\mathrm{S}$
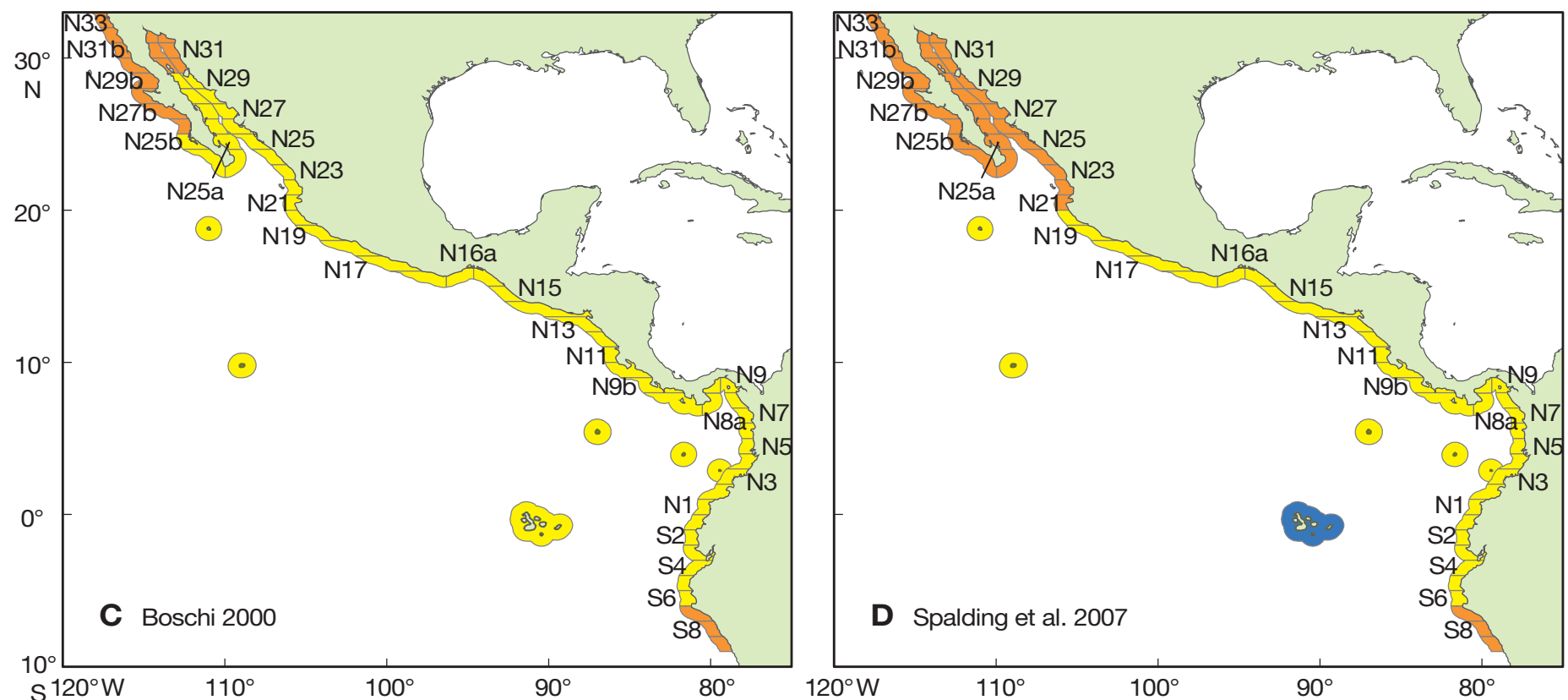

Fig. 1. Biogeographic provinces within the Tropical Eastern Pacific (TEP) proposed by: (A) Ekman (1953), Walker (1960) and Hastings (2000); (B) Briggs (1974); (C) Boschi (2000); (D) Spalding et al. (2007). Segments above and below the equator were coded N and S, respectively. Additional segments were defined for each longitudinally distinct section of coast occurring at approximately the same latitude (e.g. N25, 
primarily within the boundaries of the TEP, although their ranges may temporarily expand north and south beyond the TEP during El Niño events.

Distribution database. As the continental coast of the TEP is roughly linear and oriented along a north-south axis, we divided the continental coastline into segments of $1^{\circ}$ of latitude $(\sim 110 \mathrm{~km}$; Fig. 1). Segments above and below the equator were coded $\mathrm{N}$ and $\mathrm{S}$, respectively. Along more complicated parts of the coastline (e.g. that including the Pacific coast of Baja and the east and west shores of the Gulf of California) and where the coastline is oriented more east-west (the coasts of Panama and southern Mexico), additional separate segments were defined for each longitudinally distinct section of coast occurring at approximately the same latitude (e.g. N25, N25a, N25b in Fig. 1A for the Gulf of California and Baja). Each of the 5 ocean islands/archipelagos (the Revillagigedos, Clipperton, Cocos, Malpelo and Galapagos) was assigned a single, separate segment.

Small ocean islands, such as the 5 in the TEP, typically have smaller fauna than adjacent continental areas (e.g. Robertson 2001). To help understand the effects of large differences in fauna size on provincial relationships involving the ocean islands, we provided a separate segment for the only near-shore island for which the shore fish fauna is comprehensively known-Gorgona Island, Colombia. In addition, 'peripheral segments' of the continental shore adjacent to the northern and southern boundaries of the TEP were included in the analysis: 8 segments north of $25^{\circ} \mathrm{N}$ on the Pacific coast of Baja (California Province), and 3 segments south of $5^{\circ} \mathrm{S}$ (Peruvian Province). These were included to help define the position of the northern and southern boundaries of the TEP. With these the database comprised species presence-absence information in each of the 72 total segments included in the analyses. The shore fish fauna of each continental segment included any species, with certain exceptions whose continental range spanned that segment, while the fauna of the 5 ocean islands/archipelagos and Gorgona included the current list of species known to occur at that island or archipelago (see Robertson \& Allen 2006). The exceptions to this included species whose ranges are known to be disjunct, e.g species with antitropical distributions that enter the northern and southern fringes of the TEP.

Certain shore fish species were not included in the species lists for some segments, as they are not included in the original database. These include the substantial number of temperate species occurring in peripheral segments but not between $25^{\circ} \mathrm{N}$ to $5^{\circ} \mathrm{S}$ along the continental coastline, as well 4 shallowwater species endemic to the northernmost part of the Gulf of California $\left(30^{\circ}\right.$ to $\left.33^{\circ} \mathrm{N}\right)$. In addition, due to the absence of natural reef habitats within the Sinaloan and Central American Gaps, segments within those gaps that lacked such habitat (N24-25, and N15-16, respectively) were assumed to have no reef fishes. Reef fishes were included in segments N14 and N16a, as these segments contain both soft bottom and reef habitats. The latter includes Cobanos Reef, just south of $14^{\circ} \mathrm{N}$ near the El Salvador/Guatemala border (see Orellana 1985, Glynn \& Ault 2000).

Analytical methods. Hierarchical agglomerative clustering was used to determine geographic groupings of the 72 segments from a matrix of similarity values for all segment pairings. Bray-Curtis similarity was used, as it is appropriate for presence-absence data and does not treat joint absences as evidence of similarity between groups (Bray \& Curtis 1957, Clarke 1993). The clustering algorithm proceeded using the average linkage method to compare the average similarity values of all segment pairs within a cluster.

Analysis of Similarity (ANOSIM; Clarke 1993) was used to refine the cluster groupings ('groups') by determining whether there was a statistically significant difference between groups. ANOSIM computes a test statistic $R$, which is a standardized comparison of the average ranked Bray-Curtis pairwise similarity value between groups of segments $\left(r_{\mathrm{b}}\right)$ and the average ranked similarity value within a group $\left(r_{\mathrm{w}}\right)$. For each combination of group pairings, $R$ is calculated as:

$$
R=\left(r_{\mathrm{b}}-r_{\mathrm{w}}\right) /[n(n-1) / 4]
$$

where $n$ is the total number of coastal and island segments in the groups being compared. $R$ scales from -1 (all segments within a group are less similar to each other than to segments from other groups) to +1 (all segments within a group are more similar to each other than to segments from other groups). An $R$ value was computed for the overall group configuration ( $\left.R_{\text {overall }}\right)$ and for group pairs $\left(R_{\text {pairwise }}\right)$. A significance value was computed for $R_{\text {overall }}$ and $R_{\text {pairwise }}$ by the random reshuffling of segments among groups to determine if observed $R$ values were significantly different from those expected by chance. This permutation procedure was performed 1000 times for each analysis. To provide a starting point that eliminated the most unlikely configurations for the ANOSIM computations preliminary groups were determined from the similarity dendrograms from the clustering analyses by cutting the dendrograms at $75 \%$ of the distance from the greatest dissimilarity between clusters. The final biogeographic grouping pattern was determined by iteratively changing the arrangement of segments within preliminary clusters to arrive at the configuration that produced the highest $R_{\text {overall }}$ value for which $R_{\text {overall }}$ and all the $R_{\text {pairwise }}$ values were significant at the $95 \%$ level.

Cluster configurations from 3 different cluster linkage methods (Average, Complete, and Ward's; see 
McCune et al. 2002) and 4 different similarity metrics (Bray-Curtis, Sorensen's, Manhattan, and Euclidean; see Legendre \& Legendre 1998) were explored during this iterative process to ensure that all reasonable province configurations were investigated. Although both clustering and ANOSIM analyses evaluate the same matrix of Bray-Curtis dissimilarity values, they occasionally produced slightly different groupings (see 'Results' and 'Discussion') because they use the matrix in different ways: averages of similarity values versus the ranks of those values, respectively. Clustering and ANOSIM analyses were carried out using Community Analysis Package v3.11 (PISCES Conservation 2004).

Types of fishes. Previous assessments of regional subdivisioning of shore fishes have focused on reef fishes (Walker 1960, Rosenblatt 1967, Briggs 1974, Thomson et al. 1979) or specific taxa of such fishes (Hastings 2000). Here, we examine the distributions not only of all TEP residents but also of various subsets of that fauna to understand how those subsets contributed to the overall pattern of zoogeographic subdivisions. Those subgroups included TEP endemics and 3 functional groups of residents and endemics, i.e. species restricted to each of 3 habitat types: (1) reef fishes (demersal, restricted to the hard bottoms of coral- and rock reefs); (2) soft-bottom fishes (demersal, restricted to mud and sand bottoms); and (3) coastal pelagic fishes (non-demersal, live only in the water column).

Differences in faunal richness and faunal composition. Delimitation of biogeographic regions and subregions with dissimilar faunas typically takes into account levels of endemism and differences in faunal richness or diversity between areas (e.g. Ekman 1953, Briggs 1974, Fox \& Beckley 2005). However, dissimilarities in the faunas of 2 areas reflect a combination of levels of differences in both species richness and species assemblage. In the present case, estimating the contributions of faunal richness and faunal composition to dissimilarity is most important for determining how the ocean islands fit into the regional picture, because the greatest disparities in faunal richness occur between the ocean islands (smaller faunas) and areas of the mainland (larger faunas).

The relative contribution of differences in faunal richness and faunal composition to the observed dissimilarity values among sites (provinces and islands) was determined by comparing the size-difference dissimilarity value for a site pair (derived by assuming that the smaller site fauna is composed entirely of a subset of the larger site fauna) with the total dissimilarity value (the actual observed value) between the same site pair. The proportion of the dissimilarity between 2 sites that is due to a difference in species composition between them was calculated as:

$$
\mathrm{A}=1-(\mathrm{B} / \mathrm{C})
$$

where $\mathrm{A}$ is the proportion of dissimilarity due to faunalcomposition difference, $\mathrm{B}$ is the proportion of dissimilarity due to faunal-size difference, and $\mathrm{C}$ is the total dissimilarity.

Local endemics and species richness. Patterns of endemism and richness in the shore fish fauna were examined to assess their influence on the provincial divisions indicated by the clustering/ANOSIM analyses. The abundances of species in various subsets were computed within each segment in the TEP, including that for each ocean island. These included: (1) the absolute abundance of all TEP residents; (2) the relative abundance of the 3 functional (habitat) groups; and (3) the absolute and relative abundance of species with small to moderate range sizes: those restricted to 1 segment, to 5 or fewer segments, and to up to 10 segments (i.e. 1.6, 8.2 and $16.4 \%$ of the TEP, respectively). Rates of local endemism (exclusive occurrence) were also assessed for each ocean island and each mainland province.

Potential biases. The exclusion of species found only in the peripheral segments or in the northern Gulf of California as well as the inclusion of temporary range extension data beyond the TEP could potentially increase the faunal similarity between those peripheral areas and nearby areas within the TEP, and hence extend the limits of the TEP beyond those used to initially define the boundaries $\left(25^{\circ} \mathrm{N}\right.$ and $5^{\circ} \mathrm{S}$, respectively). The exclusion of 4 species endemic to the far northern part of the Gulf of California seems unlikely to produce a significant bias in the results, as $\sim 250$ species of residents occur in that area. The exclusion of reef fishes from segments within the Sinaloan and Central American Gaps that lack reef shoreline certainly enhances the definition of those gaps in any cluster analyses but does not prevent clusters of segments (or provinces) from spanning those gaps, which indeed they do (see 'Results').

\section{RESULTS}

\section{Continental limits of the TEP}

In all but 1 of 8 datasets the northern boundary of the TEP (represented by the boundary of either the Cortez or the Panamic Province) was placed at $25^{\circ} \mathrm{N}$, in the vicinity of Magdalena Bay on the west coast of Baja California (Figs. 2 \& 3). With endemic reef fishes, however, that boundary moved south to the tip of the Baja peninsula (Fig. 3B). ANOSIM and clustering results differed in their placement of the northern boundary for resident reef fishes; at $25^{\circ} \mathrm{N}$ and the tip of Baja, respectively (Fig. 2B, Fig. A1B in Appendix 1; www.intres.com/articles/suppl/m380p001_app.pdf). Thus, the 


\begin{tabular}{|l|lll|}
\hline Island A & Cortez & Panamic & \\
Island B & Mexican & Californian and Peruvian & Sinaloan and Central American Gaps \\
\hline
\end{tabular}

\section{Residents}
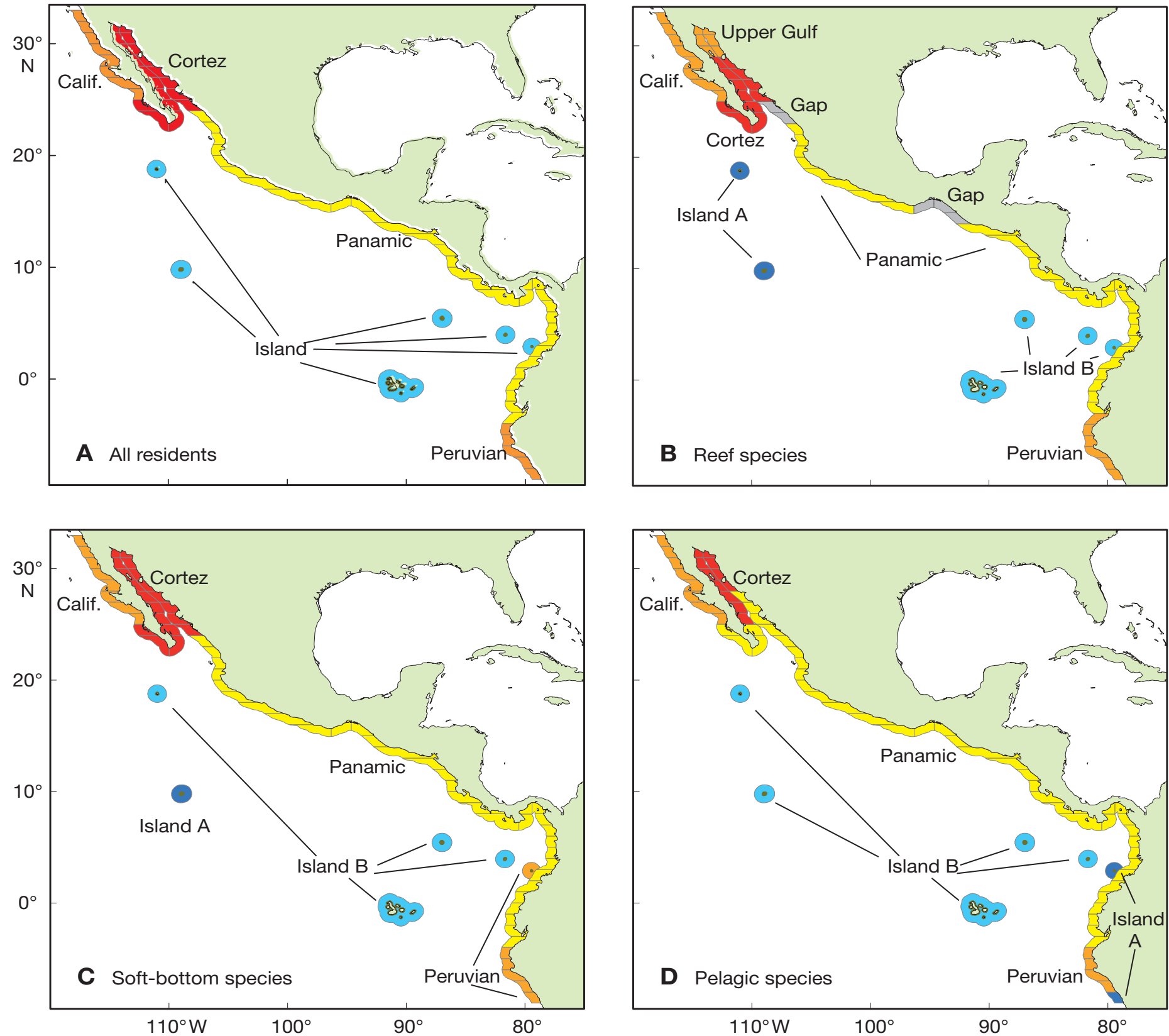

Fig. 2. Resident fishes: configurations of provinces of the Tropical Eastern Pacific (TEP) as determined from clustering analysis refined by Analysis of Similarity (ANOSIM) 


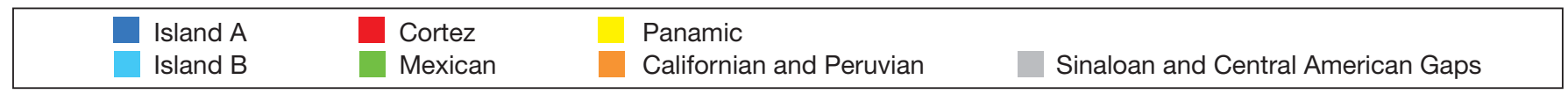

\section{Endemics}
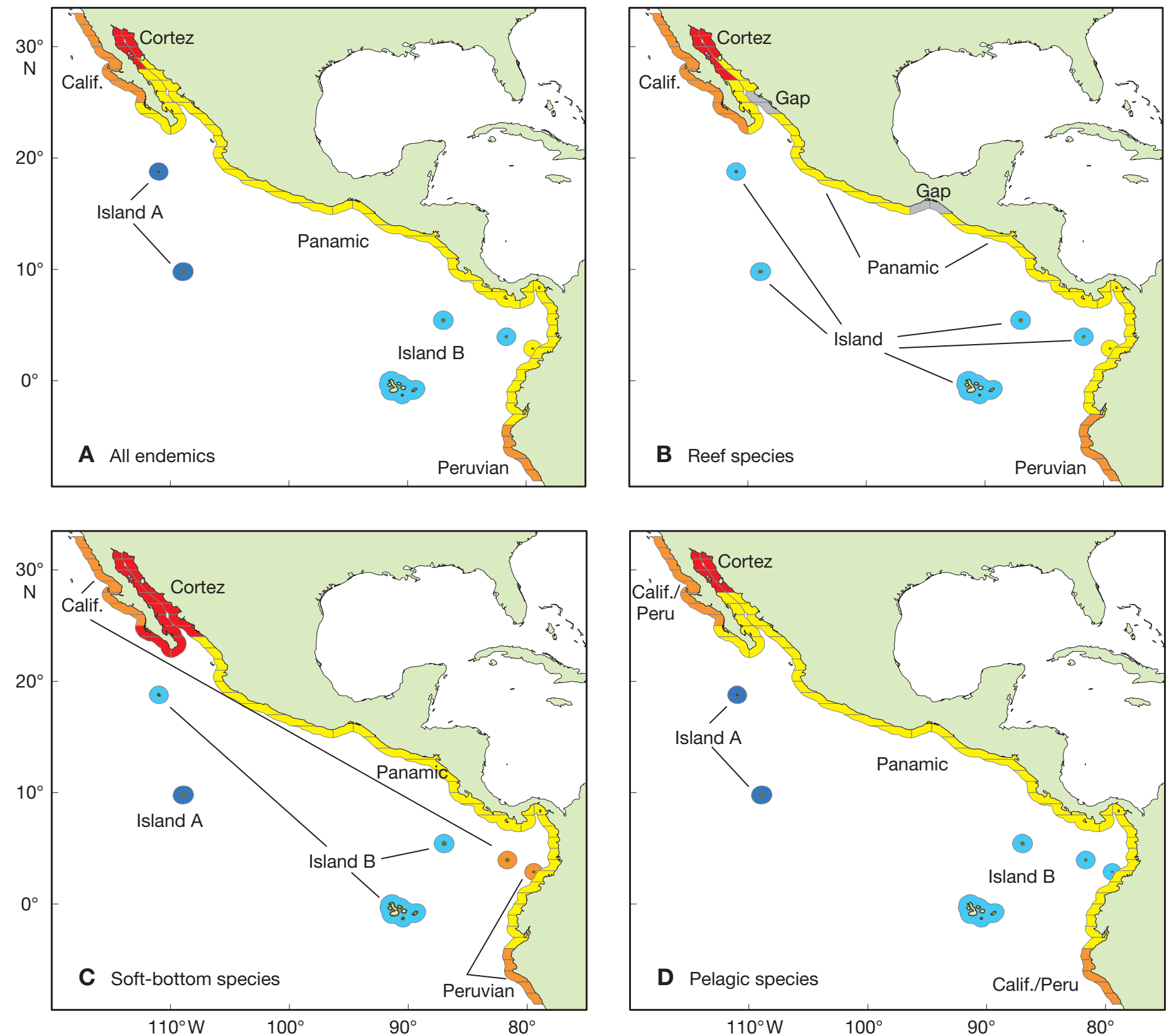

Fig. 3. Endemic fishes: configurations of provinces of the Tropical Eastern Pacific (TEP) as determined from clustering analysis refined by Analysis of Similarity (ANOSIM). 
Magdalena Bay limit is a tenuous one for reef fishes. The southern border of the TEP was located at the southern corner of the mouth of the Gulf of Guayaquil at $4^{\circ} \mathrm{S}$ (Figs. $2 \& 3$ ), in all cases except for reef fishes (residents and endemics), in which it moved to the head of that gulf at $3^{\circ} \mathrm{S}$ (Figs. 2B \& 3B).

\section{Continental coast subdivisions}

Analysis of the entire fauna and its various subsets indicated that the northern and southern temperate areas bordering the traditionally defined TEP (i.e. the Californian and Peruvian Provinces) are quite distinct not only from the TEP but also from each other (Figs. 2 \& 3, and A1 \& A2 in Appendix 1).

For residents, the TEP mainland was divided into 2 areas: an area equivalent to the Cortez Province (southern Baja and the Gulf of California), and an area comprising the rest of the continental coast of the TEP $\left(R_{\text {overall }}=0.93, \mathrm{p}<0.001 ;\right.$ Fig. 2A). For TEP endemics the region was subdivided in a similar manner, but with the Cortez Province restricted to the northern part of the Gulf of California $\left(R_{\text {overall }}=0.94, \mathrm{p}=0.001 ;\right.$ Fig. $\left.3 \mathrm{~A}\right)$. A Cortez/Mexican/Panamic provincial configuration (Fig. 1A) had noticeably lower ANOSIM $R$ values than the Cortez/Panamic configuration for both residents $\left(R_{\text {overall }}=0.76, \mathrm{p}<0.001\right)$ and endemics $\left(R_{\text {overall }}=0.85\right.$, $\mathrm{p}=0.001$ ). For TEP residents, ANOSIM (Fig. 2A) and clustering results (Fig. A1A in Appendix 1) both show the Cortez Province occupying the entire Gulf of California. For TEP endemics, ANOSIM (Fig. 3A) and clustering results (Fig. A2A in Appendix 1) both reduced the Cortez Province to the northern part of the Gulf of California, with the clustering indicating that the fauna of the southern gulf was well differentiated from that of continental shore south of that area.

Analyses of the 3 functional groups produced varying arrangements of the Cortez Province. For softbottom fishes the Cortez Province assumed the same form as for all residents (Figs. 2C \& 3C), but was restricted to the northern Gulf of California for reef and pelagic fishes (Figs. 2B,D \& 3B,D, respectively). Further, for resident reef fishes (but not endemic reef fishes) the northern part of the Gulf joined the Californian Province (Figs. 2B \& 3B). For resident pelagic fishes the southern part of the Gulf of California merged into the Panamic Province, leaving the upper part as a cohesive group of segments that we term the 'Cortez' Province, but which, according to the clustering analyses, is more distinct from the Panamic Province than are either the Peruvian or Californian Provinces (Fig. A1D in Appendix 1).

A province equivalent to the 'Mexican Province' of Walker (1966) and Hastings (2000) did not emerge in any ANOSIM result. In the clustering dendrograms for each of the functional groups the 'Mexican Province' segments were linked either to the Panamic Province (all, reef and soft-bottom residents; and all and softbottom endemics; Figs. A1A-C \& A2A-C in Appendix 1) or to the southern portion of the Cortez Province (endemic reef and pelagic fishes; Fig. A2B,D in Appendix 1). For resident pelagic fishes, segments belonging to the 'Mexican Province' were split between the Panamic and southern part of the Cortez Province (Fig. A1D in Appendix 1). For both 'complete' faunal components (all residents and all endemics) segments in southern Mexico were more similar to those further south in the TEP than groups of segments within different parts of the Cortez Province were to each other (Figs. A1A \& A2A in Appendix 1). Thus, our analyses do not provide meaningful support for the existence of a Mexican province.

The Sinaloan and Central American Gaps emerged as distinctive entities in the ANOSIM results only for resident and endemic reef fishes (Figs. 2B \& 3B), which reflects the fact that no reef fishes were included in the faunas of reef-free segments in each gap.

\section{Ocean islands and Gorgona Island}

A single Ocean Island Province was defined for allresidents (Fig. 2A), but all-endemics were divided into a northern group (Revillagigedos + Clipperton) and a southern group (Cocos + Malpelo + Galapagos) (Fig. 3A). Partitioning of the ocean islands varied among the functional groups: 1 group for endemic reef fishes (Fig. 3B) and resident pelagics (Fig. 2D), and 2 groups for resident reef and soft-bottom fishes (Fig. 2B,D) and for endemic soft-bottom fishes and pelagics (Fig. 3D). These 2 groups were: (1) Clipperton (alone or with the Revillagigedos) and (2) the remainder of the ocean islands (Malpelo, Cocos, Galapagos). The exception to the 1 or 2 Ocean Island Province arrangement was for endemic soft-bottom fishes, in which Malpelo was linked to the Californian Province rather than to any other ocean island (Fig. 3C). The clustering dendrograms show that there invariably were strong differences between the faunas of each of the islands, differences typically as great as those between mainland areas (Figs. A1 \& A2 in Appendix 1).

The linkage of the Gorgona fauna to other parts of the TEP varied among the different faunal subsets: to the nearest ocean islands in 3 cases (all and reef residents, endemic pelagics), and to the adjacent mainland segments in the remaining 5 cases (Figs. $2 \& 3$ ). The clustering dendrograms (Figs. A1 \& A2 in Appendix 1) invariably linked Gorgona with the mainland. 
Table 1. Contribution of differences in faunal composition (as opposed to faunal size) to levels of dissimilarity between the faunas of Tropical Eastern Pacific (TEP) resident species at different sites. Below diagonal: Bray-Curtis (B-C) dissimilarity value for the fauna of each pair of sites. Above diagonal: proportion of each B-C dissimilarity value due to differences in faunal composition (see 'Materials and methods' for computation). Cortez and Panamic Provinces are as in Fig 2A. No. in parentheses to right of site name: no. of species; na: not applicable

\begin{tabular}{|c|c|c|c|c|c|c|c|c|c|}
\hline & \multicolumn{6}{|c|}{ - Ocean islands } & \multicolumn{3}{|c|}{$\longrightarrow$ Continental coast -} \\
\hline & Clipperton & Cocos & Galapagos & Malpelo & Revilla. & All & Gorgona & Cortez & Panamic \\
\hline \multicolumn{10}{|l|}{ Ocean islands } \\
\hline Clipperton (156) & - & 0.25 & 0.13 & 0.34 & 0.33 & na & 0.40 & 0.07 & 0.05 \\
\hline $\operatorname{Cocos}(301)$ & 0.42 & - & 0.48 & 0.98 & 0.79 & na & 0.81 & 0.22 & 0.09 \\
\hline Galapagos (419) & 0.53 & 0.32 & - & 0.52 & 0.44 & na & 0.81 & 0.39 & 0.19 \\
\hline Malpelo (298) & 0.47 & 0.30 & 0.35 & - & 0.81 & na & 0.76 & 0.17 & 0.04 \\
\hline Revillagigedos (259) & 0.37 & 0.35 & 0.42 & 0.36 & - & na & 0.69 & 0.11 & 0.09 \\
\hline All (578) & na & na & na & na & na & na & 0.42 & 0.67 & 0.39 \\
\hline \multicolumn{10}{|l|}{ Continental coast } \\
\hline Gorgona (356) & 0.66 & 0.45 & 0.42 & 0.37 & 0.50 & 0.41 & - & 0.21 & 0.01 \\
\hline Cortez (751) & 0.71 & 0.55 & 0.46 & 0.52 & 0.55 & 0.39 & 0.45 & - & 0.47 \\
\hline Panamic (946) & 0.75 & 0.57 & 0.48 & 0.55 & 0.63 & 0.40 & 0.46 & 0.22 & - \\
\hline
\end{tabular}

\section{Contribution of faunal richness and faunal composition to biogeographic subdivision}

For TEP residents (Table 1), the dissimilarity between the 2 mainland provinces we identified $(0.22)$ was distinctly less than dissimilarities among either individual ocean island pairs (mean $=0.39$, range $=$ 0.30 to 0.53 ), among mainland province/ocean island pairs (mean $=0.58$, range $=0.46$ to 0.75 ), or among the 2 mainland provinces and the Ocean Island Province (range $=0.39$ to 0.40 ). In other words, the 2 mainland provinces were more similar to each other than either was to the ocean islands (individually or collectively), or the individual islands were to each other.

Almost half the mean between-site dissimilarity was due to differences in faunal composition in the following cases: (1) between the mainland provinces; (2) between the ocean islands (as a group) and the mainland provinces; and (3) between the different ocean islands. A distinctly smaller average proportion of the dissimilarity between individual ocean islands and the mainland provinces was due to faunal composition (mean $=0.14$, range 0.04 to 0.39 , with the highest value from the Galapagos/Cortez comparison). That is, faunal composition differences were responsible for little of the dissimilarities between individual ocean islands and the mainland, but were responsible for higher proportions of the dissimilarities between those islands as a group and the mainland provinces and the dissimilarity between the 2 mainland provinces.

The dissimilarity between Gorgona and the ocean islands and the proportion of that dissimilarity due to faunal composition differences followed much the same pattern as that observed between ocean islands and the mainland provinces, with one exception: the dissimilarity due to faunal composition was notably higher for individual ocean island comparisons (mean $=0.69$, range $=0.40$ to 0.81$)$. Relatively little (0.01 to 0.21) of the dissimilarity between Gorgona and the mainland provinces was due to faunal composition differences. Both of these patterns derive from the fact that the small Gorgona fauna consists almost entirely of a subset of the fauna of the adjacent mainland Panamic Province.

\section{Regional distribution of species richness, functional groups, and local endemism}

Species richness peaked in the center of the Panamic Province (Costa Rica and Panama), but was fairly high throughout most of the mainland of the TEP, except in the northern part of the Gulf of California and in the Sinaloan and Central American Gaps (Fig. 4A). Within the Cortez Province there was a peak in richness at the tip of Baja (Fig. 4A). Species richness at each ocean island and Gorgona was distinctly lower than on most of the mainland, with the exception of the species-poor mainland areas referred to above.

Compared to continental sites, the ocean island faunas had higher proportions of reef fishes, somewhat higher proportions of pelagic species, and smaller proportions of soft-bottom species (Fig. 4B). The composition of the Gorgona fauna was similar to that of adjacent mainland areas with reef habitats (Fig. 4B).

There were 3 regional peaks in both absolute and relative abundance of 2 categories of TEP endemics that have small geographic ranges (those restricted to 1 segment, and to $\leq 5$ segments): one at Panama, another, smaller peak at the tip of Baja California, and a third and largest peak at the ocean islands. (Fig. 4C,D). Rates of local endemism ranged from 2.5 to 

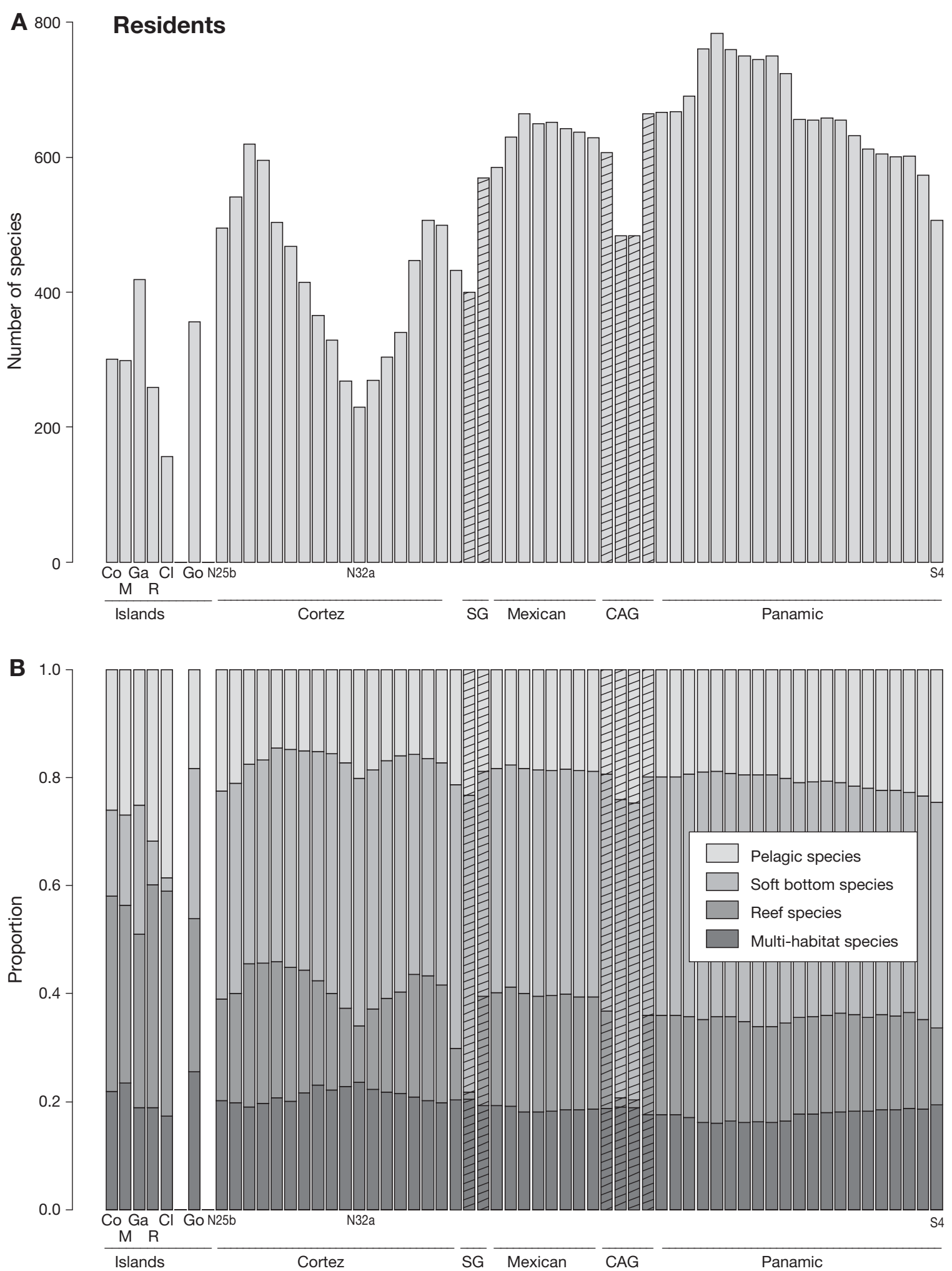

Fig. 4. (Above and facing page.) Distribution of species richness and endemicity among the islands and provinces of the Tropical Eastern Pacific (TEP). Province boundaries from Hastings (2000), with cross-hatching indicating segments of the Sinaloan Gap (SG) and Central American Gap (CAG). (A) Number of species of TEP residents in each of the 72 segments in the study area. (B) Proportion of TEP residents in each segment that have different habitat associations. (C) Number of species of TEP endemics 

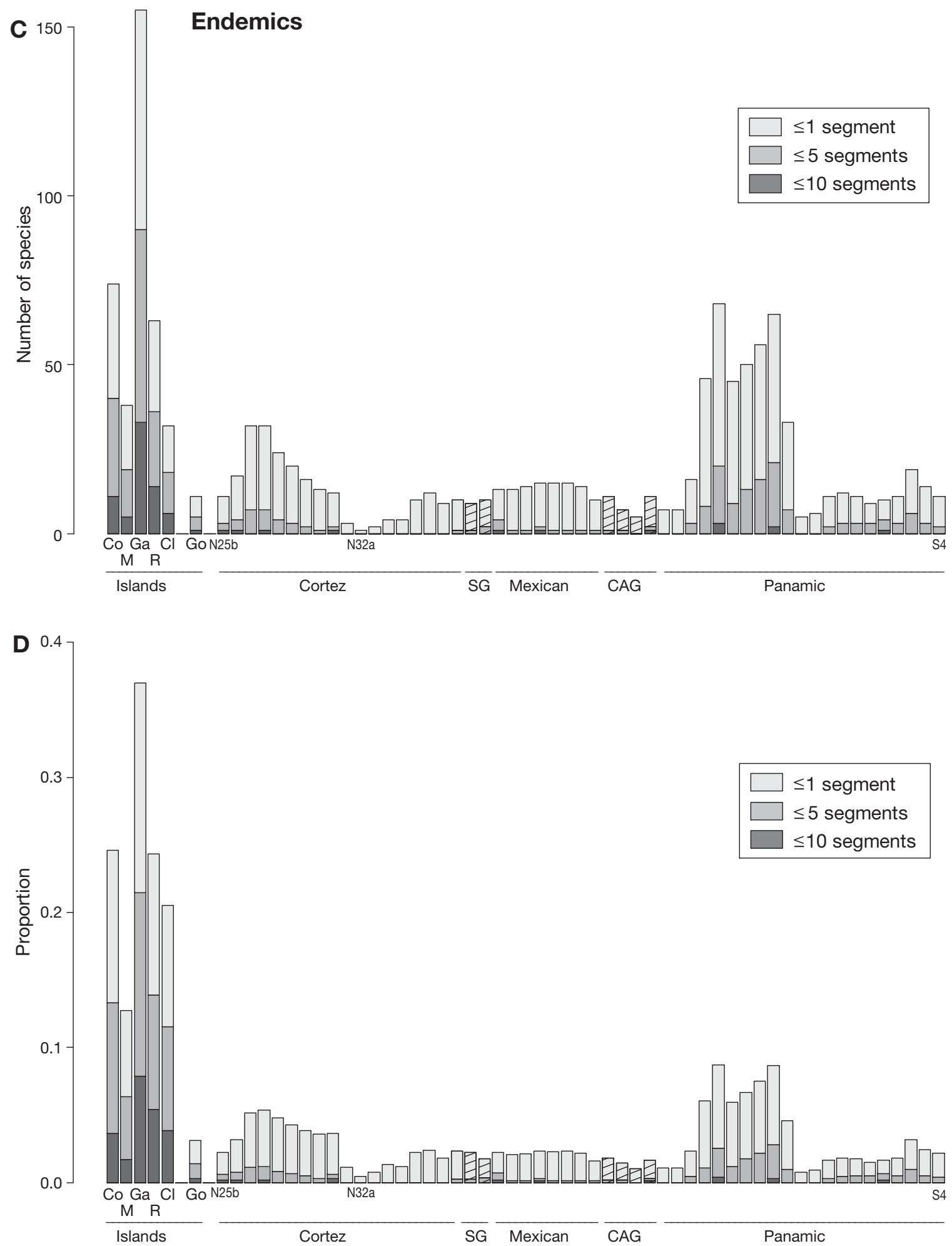

with restricted latitudinal ranges (1 segment and up to 5 segments). (D) Proportion of TEP residents in each segment that represent TEP endemics with restricted latitudinal ranges. Co: Cocos; Ga: Galapagos; Cl: Clipperton; Go: Gorgona; M: Malpelo; R: Revillagigedos 
$10.5 \%$ among the individual ocean islands and 2.3 to $18 \%$ among the mainland provinces (Table 2). Besides its own local endemics the fauna of each of the ocean islands also includes insular endemics that occur on multiple ocean islands. Similarly, each mainland province fauna also includes continental endemics found in multiple provinces as well as local endemics. Addition of these wider-spread insular and continental endemics to the island and mainland fauna substantially increased levels of endemism on the individual islands and the mainland provinces (Table 2). The 'Mexican Province' of previous studies had a much lower level of local endemism than either the Cortez or Panamic provinces, and a lower level than any of the individual islands (Table 2).

\section{DISCUSSION}

\section{Northern and southern limits of the TEP}

Our results provide strong support for a northern limit of the TEP at $\sim 25^{\circ} \mathrm{N}$ (in the vicinity of Magdalena Bay on the Pacific coast of Baja) and a southern limit at $\sim 4^{\circ} \mathrm{S}$ on the south of the Gulf of Guayaquil. Those limits were slightly more restricted for reef fishes $\left(23^{\circ} \mathrm{N}\right.$ and $3^{\circ} \mathrm{S}$ ), likely reflecting the paucity of appropriate habitat at those limits. These $25^{\circ} \mathrm{N}$ and $4^{\circ} \mathrm{S}$ limits are in general concordance with those proposed in previous analyses (e.g. Hastings 2000, Briggs 1974), except that of Spalding et al. (2007).

Table 2. Levels of endemism among inshore fishes at the ocean islands and continental coast provinces of the Tropical Eastern Pacific (TEP). Inshore fishes: species restricted to inshore waters, which rely exclusively on shoreline habitats. Local endemics: TEP endemics restricted to that site, forming a subset of insular (I) or continental (C) endemics. I: all TEP endemics restricted to islands; $\mathrm{C}$ : all TEP endemics restricted to the continental coast

\begin{tabular}{|c|c|c|c|}
\hline \multirow[t]{2}{*}{ Site } & \multirow{2}{*}{$\mathrm{N}_{\text {species }}$} & \multicolumn{2}{|c|}{ Endemics } \\
\hline & & Local & I or $\mathrm{C}$ \\
\hline \multicolumn{4}{|l|}{ Ocean islands } \\
\hline Clipperton & 104 & 5.8 & 13.4 \\
\hline Cocos & 259 & 4.6 & 13.1 \\
\hline Galapagos & 363 & 10.5 & 15.4 \\
\hline Malpelo & 203 & 2.5 & 6.9 \\
\hline Revillagigedos & 212 & 8 & 12.7 \\
\hline All ocean islands & 515 & 20.2 & 20.2 \\
\hline \multicolumn{4}{|l|}{ Continental coast } \\
\hline Cortez $^{a, b}$ & 698 & 8.9 & 43.4 \\
\hline Mexican $^{a}$ & 619 & 2.3 & 48.4 \\
\hline Panamic $^{\mathrm{a}}$ & 820 & 18 & 49.5 \\
\hline Enlarged Panamic ${ }^{\mathrm{b}}$ & 895 & 22.6 & 51.3 \\
\hline
\end{tabular}

\section{Continental coast provinces}

Collectively our analyses strongly indicate that there are only 2 provinces on the continental shores of the TEP, a Cortez Province and a Panamic Province. Differences between the fauna of the Mexican Province of Walker (1960) and Hastings (2000) and the remaining parts of the mainland evidently are not sufficient to warrant separate provincial status for southern Mexico, or a 3-province arrangement of the continental shoreline. For the different faunal subsets, the 'Mexican' region was variously linked to either the north (Cortez Province), the south (bulk of the Panamic Province) or was divided between the two. Although its fauna is similar in size to the remainder of the Panamic Province, the 'Mexican' area has very few local endemics in comparison to either the Cortez Province or the southern section of the Panamic Province. As the number of local endemics shared by the Mexican area plus Cortez Province $(\mathrm{n}=46)$ is about the same as that shared by the 'Mexican' area plus the remainder of the Panamic Province $(n=50)$, the 2 province arrangement largely reflects the paucity of local endemics and the abundance of widespread species in the 'Mexican' area.

From an entire-fauna perspective the Cortez Province defined by our analyses corresponds to that of Walker (1960) and Hastings (2000). However, among various subsets of the fauna the area with a distinct Cortez fauna ranged from the entire Gulf of California plus the southern Pacific coast of Baja California, to just the top part of the Gulf. Among reef fishes, the object of most previous analyses of the Cortez fauna, the Cortez Province was restricted either to the southern and central part of the Gulf (residents) or the northern half (endemics). The Gulf of California is at the latitudinal limit of the TEP, and has a strong environmental gradient along the $9^{\circ}$ of latitude of its length, with a small subtropical area supporting coral reefs at its southern mouth grading into a distinctly temperate area at its northern head. The variation in the extent of the Cortez Province among different subgroups of the fauna likely reflects: (1) varying responses of different groups to that environmental gradient, and (2) the importance and distribution of various types of non-endemics in different parts of the Gulf, including the relatively small proportion of temperate (Californian) species.

In only one instance did our analyses provide any support for Briggs' (1974) assertion that the northern and central part of the Gulf of California represents an isolated outpost of the California Province rather than being part of the TEP: for resident reef fishes the northern quarter of the Gulf was linked to the California Province rather than the rest of the Cortez Province. Since the same pattern was not seen for TEP endemic reef fishes, this northern Gulf/California 
affinity evidently arises from the importance of nonendemic 'Californian' species in the small ( 60 species) northern Gulf reef fish fauna.

Our analyses provide no support for the exclusion of the Gulf of California and Baja from the TEP and their inclusion in the Californian Province, an arrangement proposed by Spalding et al. (2007). Hastings et al. (in press) also maintain that the entire Gulf of California is part of the TEP, because the Gulf fauna is primarily tropical, the great majority of species found there also occur south of the Gulf while less than one-third occur in the Californian Province (many of them vagrants carried northwards by El Niño-driven currents), and only $2 \%$ have primarily Californian distributions.

\section{Ocean Island Province}

Results of the whole-fauna analyses indicate that the ocean islands fall into a single province. The other alternative configuration resulting from various faunal subsets is a Northern Island Province (Revillagigedos + Clipperton) and a Southern Island Province (Cocos + Malpelo + Galapagos). In the faunal subsets in which an individual island separated off from the remaining islands (e.g. Clipperton and Malpelo in the soft-bottom fauna) very few members of the subset were present at the aberrant islands. None of our results support the idea that Galapagos represents a separate province equivalent to the Cortez or Panamic Provinces. In all cases Galapagos was linked to 2 or more of the other ocean islands. If the Galapagos were classed as a separate province, then, given the extent of faunal differences among all the islands, each of the other ocean islands should also be defined as a separate province. However, the ocean islands all clearly differ from the mainland, and group together in all analyses. Hence, the single Ocean Island Province indicated by the entire-fauna analysis seems the most logical, with the Galapagos simply having the largest fauna with the greatest number of local endemics. These characteristics of the Galapagos fauna probably are due to that archipelago accounting for $95 \%$ of the ocean island habitat in the TEP, having the greatest diversity of environmental conditions of any of the ocean islands, and having experienced the greatest level of collecting effort.

What insight does the fauna of Gorgona Island provide about island/mainland differences? Although ANOSIM results occasionally attached Gorgona to the Ocean Island Province, clustering linked it more to the mainland in all but one case. Strong dissimilarities between the Gorgona and continental coast fauna were almost entirely due to that island fauna essentially being a small subset of the fauna of the adjacent mainland. With the ocean islands, however, dissimilarities between them and the continental coast are more due to differences in faunal composition. The ocean island and the continental coast fauna have differences in functional group composition and the ocean islands have a greater abundance of highly localized endemics. In addition, transpacific fishes resident in the TEP are concentrated primarily on the ocean islands and make proportionately greater contributions to the ocean island fauna than to the continental coast fauna (Robertson et al. 2004).

\section{Historical origins of the 3-province arrangement}

\section{Continental coast provinces}

The distinctiveness of the shore fish fauna of each continental province largely rests on each possessing significant numbers of local endemics and containing an small area of high overall species richness. These centers of richness occur in the 2 sections of the continental shore of the TEP with the greatest diversity of habitats and environments and with the only significant areas of continental-shelf islands (Mora \& Robertson 2005a,b). The islands of the Gulf of California have a different environment to the mainland and harbor fish assemblages different to those on the mainland shoreline (Thomson \& Gilligan 2002). Much the same occurs on the islands of Panama, as those near the edge of the continental shelf support populations of insular transpacific fishes (Rosenblatt et al. 1972). Thus, the great diversity of environmental conditions within the Gulf of California and around Panama provides those 2 areas with the capacity to support relatively diverse fauna.

The Gulf of California began to form 25 million yr ago (mya), taking its present shape as the lower Baja Peninsula arose from the fusion of a collection of islands between 3.5 and 12 mya (Holt et al. 2000). Indirect (non-geological) evidence suggests that about 1 mya Baja contained 1 to 2 mid-peninsular seaways connecting the Gulf to the Pacific, but then assumed its present form (Riddle et al. 2000). Populations of primarily Californian species became isolated in the Gulf following the completion of the formation of the Baja peninsula, or after having invaded the Gulf during glacial periods with lower temperatures. This led to speciation of isolated populations within the Gulf of California (Huang \& Bernardi 2001, Stepien et al. 2001, Bernardi et al. 2003a, Riginos 2005), events that contributed to the development of the distinctive fauna of the Cortez Province.

The formation of the Isthmus of Panama led to the diversity of habitats and environmental conditions and the abundance of continental islands that support the 
richest concentration of species in the TEP. Further, Panama was the last place to be isolated from the Caribbean by the rising Central American isthmus and thus the part of the TEP to most recently receive Caribbean migrants. Species that formed when migrants became isolated by the final closure of the isthmus were capable of living in the tropical environment of the Panama area, but not necessarily the subtropical Gulf of California. The relatively recent addition of such species to the TEP fauna contributed to the regional peak in species richness around Panama, particularly if, due to the shorter time available, fewer of the arrivals were lost to extinction than species that arrived at earlier times. If this is the case, then TEP members of geminate species pairs separated by the final closure of the isthmus (Jordan 1908) would tend to be limited to the Panamic Province if they have restricted distributions.

The Central American and Sinaloan Gaps were thought to have produced a 3-continental coast province arrangement of the TEP, by limiting the dispersal and hence distributions, of reef fishes (Springer 1959, Walker, 1960, Hastings 2000). These gaps evidently do act in this way for some reef fishes, e.g. they separate sister-species pairs of Chaenopsid blennies (Hastings 2000). In doing so, those gaps contribute to the distinctiveness of the Cortez and Greater Panamic provincial faunas. However, our data and analyses indicate that the 2 gaps have had small effects at the level of the entire regional fauna. (1) Of continental endemics, $60 \%$ span at least 1 of the 2 gaps, and $42 \%$ span both. Among species that fail to span one or both gaps (40 and $18 \%$ of the continental endemics, respectively) a species range would be expected to stop at the edge of a gap if the gap was limiting the distribution. Our data (see Robertson \& Allen 2006) indicate that range-ends are associated with gap edges among only a quarter of such species. Thus among $~ 85 \%$ of continental endemics there are little or no indications that range limits are set primarily by the gaps. (2) In the ANOSIM analyses, neither gap defined a provincial boundary in the group for which their potential effects should be most important-endemic reef fishes. (3) While the boundary between the Cortez and Greater Panamic provinces does coincide with the Sinaloan Gap, the case for that gap producing that boundary by limiting dispersal of reef fishes is weakened by the fact that it is only half the width of the Central American Gap, which does not coincide with a province boundary. Further, in soft-bottom species, the dispersal and distributions of which should not be limited by the 2 gaps, the boundary of the Cortez Province coincides with the Sinaloan Gap.

The lack of a defining role of those 2 gaps in the provincial subdivisioning of the mainland of the TEP, even among reef fishes, may derive from the gaps having relatively recent origins and/or being readily spanned by larvae of most such fishes. Our conclusion that the overall effects of the Sinaloan and Central American Gaps at the level of the regional fauna are much smaller than was previously thought could be effectively tested through range-wide genetic analyses of a variety of TEP fish taxa to assess relations between presumed conspecific populations separated by gaps as well as relations among populations in different parts of each province.

As Hastings (2000) pointed out, all present-day barriers to dispersal of marine shore organisms in the TEP are habitat barriers, principally the Sinaloan and Central American Gaps on the continental coast and the stretches of deep ocean that isolate the ocean islands. The geographic configuration of the continental shelf of the west coast of the Americas is such that eustatic variation in sea level has not produced intermittently active land barriers to dispersal, as it has in areas such as the Indo-Australian archipelago. Hence, determining whether speciation has occurred since the present configuration of barriers developed in the TEP should provide indications of the mechanisms involved. The gradually expanding set of genetic studies on TEP fishes provides some information. There are indications of speciation occurring very recently within the Gulf of California, due to environmental and habitat differences between the northern and southern sections of the Gulf (Bernardi et al. 2003a, Riginos 2005, H. Lin \& P. Hastings unpubl. data), and unrelated to major dispersal barriers. Speciation has also occurred in the southern part of the Panamic province since the closure of the Isthmus of Panama (Williams \& Reid 2004, L. Ruber unpubl. data on Gobioides). In the absence of hard dispersal barriers within that part of the TEP following the closure of the isthmus, environmental differences in various parts of the Panamic Province also become implicated in post-isthmian speciation.

Speciation events between the Cortez and southern Panamic Provinces occurred among shore organisms not only before the closure of the Isthmus of Panama (Lessios et al. 1995, Ruber et al. 2003, unpubl., Williams \& Reid 2004) but also after that event (Banford et al. 1999, Williams \& Reid 2004, H. A. Lessios \& D. R. Robertson unpubl. data on Stegastes, L. A. Rocha \& D. R. Robertson unpubl. data on Halichoeres). The fact that the only continental barriers to dispersal of shore fishes between the Gulf of California and the southern TEP, the Sinaloan and Central American Gaps, are not of primary importance in defining provincial boundaries weakens the argument that such recent betweenprovince speciation events are due to allopatric speciation. Rather, environmental differences between the subtropical and equatorial parts of the region seem 
more likely to be involved in such events without complete isolation of populations, events that have lead to the development of differences between the fauna of the northern and southern TEP and contributed to the Cortez + Greater Panamic provincial arrangement of the continental shore.

\section{Ocean Island Province}

The shore biota of the TEP is partly isolated from the shore biota of the central Pacific by the Eastern Pacific Barrier (EPB). Despite its great breadth the EPB has evidently been crossed repeatedly by shore fishes, primarily by species moving eastwards to the TEP (Robertson et al. 2004, Lessios \& Robertson 2006). Migrations across the EPB both before (Bernardi et al. 2003b, Lessios \& Robertson 2006) and after (Banford et al. 2004, Lessios \& Robertson 2006) the closure of the Isthmus of Panama have led to the development of new species or isolated populations in the early stages of speciation in the TEP. Migrations across that barrier have continued to date (Lessios \& Robertson 2006), and 'transpacific' species that have made this crossing comprise $\sim 15 \%$ of the TEP shore fish fauna.

Habitat on the western side of the EPB consists exclusively of oceanic reefs, and equivalent habitat in the TEP is provided primarily by the oceanic islands and a cluster of islands on the outer continental shelf of the western Pacific coast of Panama. Transpacifics resident in the TEP are concentrated in those areas of habitat and make proportionately greater contributions to the ocean island faunas than to the continental coast fauna (Robertson et al. 2004, Robertson \& Allen 2008). Thus, transpacific fishes have a substantial role in defining the distinctiveness of the fauna of the Ocean Island Province. However, the immigration of transpacifics from the west seems to have produced few insular endemics in the TEP (e.g. see Bernardi et al. 2004), as the likely sister species of almost all of them are on the TEP continental coast or other TEP ocean islands (e.g. Hastings 2000, Muss et al. 2001, Craig et al. 2006, and see Robertson \& Allen 2006).

The ocean islands are largely lacking in habitats that occupy much of the mainland shoreline: estuaries, mangroves, sand/mud shorelines, and, because in most cases they arise abruptly out of deep water, extensive areas of soft-bottom shelf. This is responsible for the disproportionately low numbers of soft-bottom species on the islands, one of the defining characteristics of the fauna of the Ocean Island Province.

Finally, the island fauna has high rates of single and multi-island endemism. The development of insular endemics by splitting of populations between islands and the mainland, and among the islands, not only occurred before the closure of the Isthmus of Panama (Williams \& Reid 2004) but has continued since that event (Muss et al. 2001, Williams \& Reid 2004, Craig et al. 2006, H. A. Lessios \& D. R. Robertson unpubl. data on Stegastes, L. Ruber unpubl. data on Tigrigobius). This high degree of insular endemism must be due in part to the isolation of the islands, which are separated from the mainland by distances of 380 to $1075 \mathrm{~km}$, and by equal or larger distances from each other. However, certain characteristics of the distributions of shore fishes in the TEP indicate that allopatric speciation due to complete isolation seems unlikely to account for the development of many insular endemics. (1) Overall, $27 \%$ of insular endemics occur on multiple ocean islands separated by distances greater than those between the islands and the mainland, but do not occur on the continental coast (see also Lessios et al. 1999). (2) Other insular endemics can and do cross the mainland-island gaps because they are not infrequently encountered in small numbers on the mainland. (3) A total of $40 \%$ of the TEP residents have crossed the mainland-island gaps and occur on both habitats (see Robertson \& Allen 2006). These distributions indicate that deep-water areas separating islands are not highly effective barriers in many cases and that ecological/environmental differences between the islands and mainland and among the islands likely played a significant role in the development of island endemics without complete isolation of island populations, and hence, the distinctiveness of the ocean island provincial fauna.

\section{CONCLUSIONS}

The division of the TEP into 3 provinces, each with a distinctive fauna, reflects the action of a combination of processes. (1) Speciation within each province followed the formation of disjunct populations separated by hard physical barriers such as the Baja California Peninsula, the Isthmus of Panama and by expanses of deep ocean between the offshore islands and the mainland. (2) The diversity of habitats in the Gulf of California and around Panama has fostered the accumulation of species and the development of 2 mainland centers of species richness, one subtropical, the other equatorial. (3) Shallow shoreline environments of the TEP are highly variable geographically, with extreme variation in rainfall, sea temperatures ranging from equatorial to temperate, and seasonal upwelling systems scattered throughout the region. Both the mainland and the ocean islands experience a great range of such environmental variability. The ability of many species to surmount any barriers to dispersal within the TEP, and occurrence of speciation within the TEP since 
the present geographic configuration of barriers in the region was achieved, indicate that environmental and ecological differences not only between provinces but between different parts of the same province have promoted speciation in the absence of total isolation of diverging populations, and contributed to the 3-province arrangement.

Rocha \& Bowen (2008) have argued that, given the absence of hard barriers to dispersal in the sea and the great abilities of pelagic larvae of reef fishes to cross habitat barriers, parapatric speciation may be the predominant mode of speciation in coral reef fishes. The divergence of populations in different parts of the TEP that lack intervening highly effective barriers to dispersal is consistent with this mode of speciation the development of geographically distinct species in response to different environmental conditions, despite limited ongoing gene flow between them) being a significant contributor to the development of 3 distinct types of provincial fauna of the TEP.

Acknowledgements. We thank the Smithsonian Tropical Research Institute for support, C. Lennert for advice on some of the analyses, and P. Hastings for comments on a draft of the manuscript.

\section{LITERATURE CITED}

Banford HM, Bermingham E, Collette BB, McCafferty S (1999) Phylogenetic systematics of the Scomberomorus regalis (Teleostei: Scombridae) species group: molecules, morphology and biogeography of the Spanish mackerels. Copeia 596-613

Banford HM, Bermingham E, Collette BB (2004) Molecular phylogenetics and biogeography of transisthmian and amphi-Atlantic needlefishes (Belonidae: Strongylura and Tylosurus): perspectives on New World marine speciation. Mol Phylogenet Evol 31:833-851

Bernardi G, Findley L, Rocha-Olivares A (2003a) Vicariance and dispersal across Baja California in disjunct marine fish populations. Evolution 57:1599-1609

Bernardi G, Bucciarelli G, Costagliola D, Robertson DR, Heiser JB (2004) Ecology and evolution of the coral reef fish genus Thalassoma (Labridae): 1. Molecular phylogeny and biogeography. Mar Biol 144:369-375

Boschi E (2000) Species of decapod crustaceans and their distribution in the American marine zoogeographic provinces. Rev Invest Des Pesq 13:7-136

Bray JR, Curtis JT (1957) An ordination of the upland forest communities of Southern Wisconsin. Ecol Monogr 27: 325-349

Briggs JC (1974) Marine zoogeography. McGraw-Hill, New York

Chirichigno FN, Vélez JD (1998) Clave para identificar los peces marinos del Perú, 2nd edn. Instituto del Mar del Peru, Lima

$>$ Clarke KR (1993) Non-parametric multivariate analyses of changes in community structure. Aust J Ecol 18:117-143

$>$ Craig MT, Hastings PA, Pondella DJ II, Robertson DR, Rosales-Casián JA (2006) Phylogeography of the flag cabrilla Epinephelus labriformis (Serranidae): implications for the biogeography of the Tropical Eastern Pacific and the early stages of speciation in a marine shore fish. J Biogeogr 33:969-979

Ekman S (1953) Zoogeography of the sea. Sidgwick \& Jackson, London

Findley LT, Hendrickx ME, Brusca RC, van der Heiden AM, Hastings PA, Torre J (2003) Diversidad de la macrofauna marina del Golfo de California, Mexico. CD-ROM versión 1.0. Projecto de la Macrofauna del Golfo, Conservation International (www.conservation.org)

Fox NJ, Beckley LE (2005) Priority areas for conservation of Western Australian coastal fishes; a comparison of hotspot, biogeographical and complementarity approaches. Biol Conserv 125:399-410

Glynn PW, Ault JS (2000) A biogeographic analysis and review of the far eastern Pacific coral reef region. Coral Reefs 19:1-23

Hastings PA (2000) Biogeography of the tropical eastern Pacific: distribution and phylogeny of chaenopsid fishes. Zool J Linn Soc 128:319-335

Hastings PA, Findley LT, van der Heiden AM (in press) Fishes of the Gulf of California. In: Brusca R (ed) Natural history of the Gulf of California. University of Arizona, Phoenix, AR

> Holt JW, Holt EW, Stock JM (2000) An age constraint on Gulf of California rifting from the Santa Rosalia Basin, Baja California Sur, Mexico. Geol Soc Am Bull 112:540-549

Huang D, Bernardi G (2001) Disjunct Sea of Cortez-Pacific Ocean Gillichthys mirabilis populations and the evolutionary origin of their Sea of Cortez endemic relative, Gillichthys seta. Mar Biol 138:421-428

> Jordan DS (1908) The law of geminate species. Am Nat 42: $73-80$

Legendre P, Legendre L (1998) Numerical ecology, 2nd edn. Elsevier, Amsterdam

> Lessios HA, Robertson DR (2006) Crossing the impassable: genetic connections in 20 reef fishes across the Eastern Pacific Barrier. Proc R Soc Lond B Biol Sci 273:2201-2208

> Lessios HA, Allen GR, Wellington GM, Bermingham E (1995) Genetic and morphological evidence that the eastern Pacific damselfish Abudefduf declivifrons is distinct from A. concolor (Pomacentridae). Copeia 1995:277-288

> Lessios HA, Kessing BD, Robertson DR, Paulay G (1999) Phylogeography of the pantropical sea urchin Eucidaris in relation to land barriers and ocean currents. Evolution 53:806-817

Love MS, Mecklenburg CW, Mecklenburg TA, Thorsteinson LK (2005) Fishes of the West Coast and Alaska: a checklist of North Pacific and Arctic Ocean species from Baja California to the Alaska-Yukon border. US Department of the Interior, USGS, Seattle, WA

McCune B, Grace BC, Urban DL (2002) Analysis of ecological communities. MjM Software Design, Gleneden Beach, OR

- Mora C, Robertson DR (2005a) Causes of latitudinal gradients in species richness: a test with fishes of the tropical eastern Pacific. Ecology 86:1771-1782

Mora C, Robertson DR (2005b) Factors shaping the range-size frequency distribution of the endemic fish fauna of the Tropical Eastern Pacific. J Biogeog 32:277-286

> Muss A, Robertson DR, Stepien CA, Wirtz P, Bowen BW (2001) Phylogeography of Ophioblennius: the role of ocean currents and geography in reef fish evolution. Evolution 55:561-572

Orellana A JJ (1985) Marine fishes of Los Cóbanos: fishes of El Salvador. Sigma Foundation, New York

PISCES Conservation (2004) http://www.pisces-conservation. com/indexsoftdiversity.html

> Riddle BR, Hafner DJ, Alexander LF, Jaeger JR (2000) Cryptic vicariance in the historical assembly of a Baja California peninsular desert biota. Proc Natl Acad Sci USA 97: 14438-14443 
Riginos C (2005) Cryptic vicariance in Gulf of California fishes parallels vicariant patterns found in Baja California mammals and reptiles. Evolution 59:2678-2690

Robertson DR (2001) Population maintenance among tropical reef-fishes: inferences from the biology of small-island endemics. Proc Natl Acad Sci USA 98:5667-5670

Robertson DR, Allen GR (2006) Shorefishes of the tropical eastern Pacific: an information system. Version 2.0 DVDROM. Smithsonian Tropical Research Institute, Balboa

Robertson DR, Allen GR (2008) Shorefishes of the tropical eastern Pacific online information system. Smithsonian Tropical Research Institute, Balboa (available at: www. stri.org/sftep)

Robertson DR, Grove JS, McCosker JE (2004) Tropical transpacific shorefishes. Pac Sci 58:507-565

Rocha LA, Bowen BW (2008) Speciation in coral-reef fishes. J Fish Biol 72:1101-1121

Rosenblatt RH (1967) The zoogeographic relationships of the marine shore fishes of tropical America. Stud Trop Oceanogr 5:579-592

Rosenblatt RH (1974) Faunal areas. Science 186:1028-1029

Rosenblatt RH, McCosker JE, Rubinoff I (1972) Indo-West Pacific fishes in the Gulf of Chiriqui, Panama. Contrib Sci Los Angelos Co Mus 234:1-18

Ruber L, Van Tassell J, Zardoya R (2003) Rapid speciation and ecological divergence in the American seven-spined

Editorial responsibility: Charles Birkeland,

Honolulu, Hawaii, USA gobies (Gobiidae, Gobiosomatini) inferred from a molecular phylogeny. Evolution 57:1584-1598

Spalding MD, Fox HE, Allen GR, Davidson N and others (2007) Marine ecoregions of the world: a bioregionalization of coastal and shelf areas. Bioscience 57:573-583

Springer VG (1959) Systematics and zoogeography of the clinid fishes of the subtribe Labrisomini Hubbs. Publ Inst Mar Sci Univ Texas 5:417-492

Stepien CA, Rosenblatt RH, Bargmeyer BA (2001) Phylogeography of the spotted sand bass, Paralabrax maculatofasciatus: divergence of Gulf of California and Pacific Coast populations. Evolution 55:1852-1862

Thomson DA, Gilligan M (2002) Rocky-shore fishes. In: Case T, Cody M, Ezcurra E (eds) A new island biogeography in the Sea of Cortés. Oxford University Press, Oxford, p 154-180

Thomson DA, Findley LT, Kerstich A (1979) Reef fishes of the Sea of Cortez. Wiley, New York

Walker BW (1960) The distribution and affinities of the marine fish fauna of the Gulf of California. Syst Zool 9:123-133

Walker BW (1966) The origins and affinities of the Galapagos shorefishes. In: Bowman RI (ed) The Galapagos. University of California Press, Berkeley, p 172-174

Williams ST, Reid DG (2004) Speciation and diversity on tropical rocky shores: a global phylogeny of snails of the genus Echinolittorina. Evolution 58:2227-2251

Submitted: August 14, 2008; Accepted: January 9, 2009 Proofs received from author(s): March 12, 2009 